\title{
Relationship between creativity and intelligence in regular students and giftedness students
}

\author{
Tatiana de Cassia Nakano ${ }^{1}$ \\ Walquiria de Jesus Ribeiro' \\ Angela Magda Rodrigues Virgolim ${ }^{2}$ \\ ${ }^{1}$ Pontifical Cathollic University of Campinas, Campinas, São Paulo, Brasil \\ ${ }^{2}$ Universidade de Brasilia, Brasilia, Distrito Federal, Brasil
}

\begin{abstract}
The present study sought to identify the relationship between creativity and intelligence in gifted students. The sample consisted of 966 participants, aged between 7 and 17 years, classified as regular students $(\mathrm{n}=867)$ and criterion group ( $\mathrm{n}=99)$ ), subdivided according to the area of prominence: academic $(n=66)$, creative/artistic $(n=33)$. The Giftedness Assessment Battery was applied to assess reasoning (verbal, logical, numerical, and abstract) and creativity (verbal and figural). The results indicated that, in the control group, the relationship between the total score for intelligence and the two types of creativity were significant and positive, and scores were higher for verbal creativity. Only the correlation between the total scores for intelligence and verbal creativity was positive and significant in the criterion group. Differences in the relationship between constructs were also found according to the identification of giftedness (academic and creative).

Keywords: giftedness; reasoning; cognitive development; thought; psychological assessment.
\end{abstract}

Relação entre criatividade e inteligência em estudantes regulares e com altas habilidades/superdotação

\begin{abstract}
Resumo
O presente estudo buscou identificar a relação entre criatividade e inteligência em alunos regulares e com altas habilidades/ superdotação. A amostra foi composta por 966 participantes, com idades entre 7 e 17 anos, classificados em estudantes regulares $(n=867)$ e grupo critério $(n=99)$, subdivididos de acordo com a área de destaque: acadêmica $(n=66)$, criativa/artística $(n=$ 33). A Bateria de Avaliação das Altas Habilidades/Superdotação foi aplicada envolvendo subtestes de avaliação do raciocínio (verbal, lógico, numérico e abstrato) e criatividade (verbal e figural). Os resultados indicaram que, no grupo controle, a relação entre o total em inteligência e os dois tipos de criatividade se mostraram significativas e positivas, sendo mais alta em relação à criatividade verbal. No grupo critério, somente a correlação entre o total de inteligência e criatividade verbal foi positiva e significativa. Diferenças na relação entre os construtos também foram encontradas de acordo com a área de identificação da superdotação (acadêmica e criativa).

Palavras-chave: superdotados, raciocínio, desenvolvimento cognitivo, pensamento, avaliação psicológica
\end{abstract}

\section{Relación entre creatividad e inteligencia en estudiantes regulares y estudiantes superdotados}

\begin{abstract}
Resumen
El presente estudio buscó identificar la relación entre creatividad e inteligencia en estudiantes regulares y estudiantes superdotados. La muestra estuvo compuesta por 966 participantes, con edades entre 7 y 17 años, clasificados en estudiantes regulares (n = 867) y grupo criterio $(\mathrm{n}=119)$, y subclasificados de acuerdo con el área de destaque: académico $(\mathrm{n}=66)$ y creativo/artístico ( $\mathrm{n}=33$ ). Se aplicó la Batería de Evaluación de la Superdotación con subpruebas para evaluar el razonamiento (verbal, lógico, numérico y abstracto) y la creatividad (verbal y figurativa). Los resultados indicaron diferentes relaciones de acuerdo con el grupo considerado. La relación entre el total en inteligencia y los dos tipos de creatividad se mostraron significativas y positivas en el grupo control, siendo mayor con relación a la creatividad verbal. En el grupo criterio, solo fue positiva y significativa la relación entre las puntuaciones totales de inteligencia y la creatividad verbal. También se encontraron diferencias en la relación entre los constructos según el área de identificación de superdotación (académica y creativa).

Palabras clave: superdotados; raciocinio; desarrollo cognitivo; pensamiento; evaluación psicológica.
\end{abstract}

Considered the skills of the 21 st century, both creativity and intelligence have been recognized as essential competencies for personal, professional, and academic success (Partnership for 21st Century Skills, 2013). Based on the idea that individual knowledge can only be discovered when both skills are studied together (Nakano, 2017, 2018), the constructs' relationship has been widely debated and studied (Lynch \& Kaufman, 2019). 
In the most current conceptions, creativity has been defined as the interaction between aptitude, process, and environment, by means of which an individual generates a product that is perceived as new and useful, within a social context (Plucker, Beghetto, \& Daw, 2004). It is considered a skill possessed by all people, at least as an undeveloped potential, that can manifest itself at different levels and domains. In the most current models, intelligence has been understood within a comprehensive taxonomic model, entitled Cattell-Horn-Carroll Intelligence (CHC). In this model, intelligence would consist of three skill levels: one general factor ( $\mathrm{g}$ factor), ten factors linked to broad areas of cognitive functioning, and about 70 specific factors related to each of the overall factors (Primi \& Nakano, 2015).

However, the relationship between intelligence and creativity is still a theme that has proved controversial in the field of Psychology and cognitive processes. Investigations have historically continued to question the existence of such relationship and its level of association, in addition to its longevity and possibility of generalization for different populations (Elisondo \& Donolo, 2010). Current studies have shown that the value of the correlation between creativity (measures of creativity as potential and divergent thinking) and intelligence will depend on which intelligence factor is being assessed. It has been possible to observe significantly high values for two of the broad factors: fluid intelligence and recovery capacity, and lower correlations with a third general factor: crystallized intelligence (Beauty \& Silvia, 2012; Kaufman, Luria, \& Beghetto, 2018; Miroshnik \& Scherbakova, 2019; Silvia \& Beauty, 2012; Silvia, Beauty, \& Nusbaum, 2013).

The proposed explanations for the relationship between creativity and intelligence are based on three views. The first considers constructs as highly interconnected, complementary, synonymous skills (Batey, Furnham, \& Safiullina, 2010; Kaufman \& Plucker, 2011; Preckel, Holling, \& Wiese, 2006). It would take an average level of intelligence for the emergence of creativity and vice versa. According to the researchers who defend this line of thought, a moderate level of intelligence would be necessary for creativity to emerge. Creative people should not only generate a large number of ideas but should also be able to analyze these ideas and intelligently identify the best and worst of them (Sternberg, 2001).

The second view considers that these are differentiated skills (Aguirre \& Conners, 2010; Cramond,
Kim, \& VanTassel-Baska, 2010). It defends the idea that a person with high intelligence could or could not be highly creative. In other words, the two constructs can manifest themselves separately. Unlike the understanding proposed by the previously presented notion, intelligence alone would not be seen as an essential factor for the determination of creative talent (Sternberg \& O'Hara, 2000). So the two constructs should be considered independently.

The third view defends the idea that these are overlapping skills (Ferrando, Soto, Prieto, Sáinz, \& Ferrándiz, 2016; Jauk, Benedek, Dunst, \& Neubauer, 2013; Karwowski \& Gralewski, 2012; Mourgues et al., 2016; Shi, Wang, Yang, \& Xu, 2017; Welter, Jaarsveld, Leeuwen, \& Lachmann, 2016). Proposes the existence of a relationship between the two constructs based on a certain level of intelligence. This aspect has proved to be the most prominent, by suggesting that the correlation between the constructs would not be linear, but dependent on the level of intelligence quotient (IQ). It is called the threshold theory (Jauk, 2013; Shi et al., 2017). According to this theory, the constructs would present a positive and significant correlation in individuals with IQ up to 120 , and a low or zero correlation would be found in those with IQ above this level (Flores-Mendoza et al., 2018). Several studies with this focus have pointed to diverse results, some supporting the threshold theory's existence, others denying it. Other studies have presented evidence of the existence of multiple thresholds (between 86 and 120) (Nakano, 2017) or even that such effect is moderated by other variables, such as personality traits, especially the factor that consists of openness to experience (Harris, Williamson, \& Carter, 2019; Liu, Liu, Chen, Song, \& Liu, 2019).

In addition to the three aspects as mentioned earlier, other results can also be found by looking into the relationship between intelligence and creativity constructs. That demonstrates that depending on the type of creativity and intelligence assessed, the meaning, significance, and magnitude of the relationship change (Barros, Primi, Miguel, Almeida, \& Oliveira, 2010; Benedek, Franz, Heeene, \& Neubauer, 2012; Benedek, Jauk, Sommer, Arendasy, \& Neubauer, 2014; Jauk et al., 2013; Kandler et al., 2016; Lee, Huggins, \& Therriault, 2014). Such diversity would result from the way that each construct construct is defined and measured (Plucker, Guo, \& Makel, 2018). Studies on the subject have the relevance of the knowledge generated by this type of investigation, aimed at surveying the correlations between creativity and intelligence, is 
fundamental for understanding the phenomenon of giftedness. The multidimensional definition adopted in Brazilian public policies (Brazil, 2010) understands that this phenomenon can manifest itself in different areas: general intellectual ability, specific academic attitude, creative thinking, leadership ability, psychomotor abilities and motivation to engagement in tasks of interest individually or in combination, and in agreement with the international consensus (Kaufman \& Sternberg, 2008; Li et al., 2009; Sternberg, 2009).

It is possible to see that both creativity and intelligence have been highlighted as one of the possible areas in which giftedness can manifest themselves. Consequently, when a high potential is identified in these areas, two types of giftedness can be identified: academic giftedness (in which a high level of intelligence is displayed) and creative-productive giftedness (in which a high level of creativity can be observed) (Renzulli, 2020). The search for answers about the interconnection of the creativity and intelligence constructs can enrich discussions within this theme in the specific case or context of giftedness. However, there are still few studies investigating this issue within this particular population.

In Brazil, studies on the relationship between creativity and intelligence in the general population are generally marked by variability of results: a significant relationship between the constructs with varying degrees of intensity (Alves \& Nakano, 2014; Milian \& Wechsler, 2018; Nakano, 2012; Nakano \& Brito, 2013; Souza \& Wechsler, 2013), absence of significant correlations (Mendonça \& Fleith, 2005; Pereira, 2001), or results changing by following per under the assessed content (Alves \& Nakano, 2015; Barros et al., 2010; Nakano, Wechsler, Campos, \& Milian, 2015; Wechsler, Nunes, Schelini, Ferreira, \& Pereira, 2010). Still, a small number of studies are based on samples composed of individuals identified as a gifted (Gonçalves \& Fleith, 2011; Maia-Pinto \& Fleith, 2004; Virgolim, 2005). Little is known about relationship between the intelligence and creativity constructs in this specific population.

Thus, the objective of the present study was to identify the relationship between creativity and intelligence in different groups (regular students and students identified with giftedness in two areas: academic and artistic). Using four different intelligence measures and two different measures of creativity, we worked with the hypothesis that the magnitude of the relationship would be influenced by the type of sample considered (control and criterion group) and the type of intelligence and creativity involved (oscillation of results according to the assessed skill).

\section{Method}

\section{Participants}

The sample considered in the present study consisted of 966 participants, out of which 523 were female. The students were elementary school students (between the $2^{\text {nd }}$ and the $9^{\text {th }}$ year $-\mathrm{n}=958$ ) and high school students (between the $1^{\text {st }}$ and the $3^{\text {rd }}$ year $-\mathrm{n}=$ 29), aged between 7 and 17 years $M=11.59, S D=$ 1.86). Participants were divided into four groups. The two main groups were: control ( $\mathrm{n}=867 ; 55 \%$ female; $M=11.4$ years; $S D=1.7$ years) and criterion $(\mathrm{n}=99$; $67.2 \%$ male; $M=12.4$ years; $S D=2.5$ ). The participants in the criterion group, in turn, were subdivided into two other groups, according to the area of prominence: academic ( $\mathrm{n}=66 ; 74.2 \%$ male; $M=12.9$ years; $S D=2.6)$, creative/artistic ( $\mathrm{n}=33 ; 66.6 \%$ male, $M=$ 12.2 years, $S D=2.5)$. The sociodemographic characteristics of each group can be visualized in more detail on Table 1.

The control group participants were from three Brazilian regions (southeast, mid-west and northeast), and came from 18 different municipal and state public schools. In the criterion group, only children/ adolescents who were participants of a specialized educational support program for students with Giftedness of the Federal District's Education Department were included. The students were identified through regular evaluation procedures traditionally used by the support program, frequently in activities developed in special resource rooms. Subsequently, the group was divided into a second subdivision, considering the area in which giftedness manifests itself (academic or creative/artistic).

It is essential to highlight the fact that the control group is numerically more extensive than the criterion group for two reasons: the predominance of the phenomenon in the population (although generally estimated between $3 \%$ and $5 \%$, according to the World Health Organization, underreporting of cases as well as difficulties in identification has made it necessary to review the current number of records in the school census, approximately 169,000 by 2018 , that is, about $0.04 \%$ of the 48 million Brazilian students in primary education according to the Ministry of Education), as well as the difficulty of access to this specific population. 
Table 1.

Composition of Sample Groups

\begin{tabular}{ccccc}
\hline & & Control Group & Academic Giftedness & Creative Giftedness \\
\hline \multirow{4}{*}{ Sex } & Female & 483 & 17 & 11 \\
& Male & 383 & 49 & 22 \\
& 2 & - & 1 & - \\
& 3 & - & 3 & 1 \\
& 4 & 114 & 4 & 4 \\
& 5 & 148 & 8 & 6 \\
& 6 & 245 & 6 & 3 \\
& 7 & 173 & 10 & 6 \\
& 8 & 90 & 7 & 2 \\
Age & 9 & 97 & 8 & 1 \\
& 10 & - & 4 & 6 \\
& 11 & - & 13 & 2 \\
& 12 & - & 2 & 2 \\
Total & Minimum & 8 & 7 & 8 \\
& Maximum & 16 & 17 & 17 \\
& Average & 11,4 & 12,9 & 12,2 \\
& SD & 1,7 & 2,67 & 2,5 \\
\end{tabular}

\section{Instrument}

Giftedness Assessment Battery - BAAH/S (Nakano \& Primi, 2012)

It is composed of four intelligence subtests (verbal, abstract, numerical, and logical) and two types of creativity subtests (visual and verbal). The reasoning subtests have 12 questions, and the participant must choose one of five answer alternatives. On the numerical subtest, participants are supposed to discover and annotate the two numbers to complete each of the series presented.

On the figural creativity subtest, participants are requested to complete ten unfinished sketches. The assessment is made considering eleven creative characteristics/indicators: fluency, flexibility, elaboration, originality, emotional expression, fantasy, movement, unusual perspective, internal perspective, use of context, and expressive titles. The scores for those characteristics were later categorized into three factors: (1) Elaboration, (2) Emotional, and (3) Cognitive.

The verbal creativity subtest is composed of five sentences that must be completed with a word, to form a metaphor. For each sentence, up to four answers can be provided, and the established relationship must be explained. The judges evaluated the quality of the metaphor created, who attributed scores, within a scale ranging from 0 to 3 points.

The psychometric qualities of $\mathrm{BAAH} / \mathrm{S}$ have already been the target of several studies, in which researchers considered the factorial structure of the condition (Nakano et al., 2015; Ribeiro, Nakano, \& Primi, 2014), analyzed items using the Item Response Theory (Nakano et al., 2015), assessed the validity of evidence through external criteria (Nakano, Primi, Ribeiro, \& Almeida, 2016), and observed convergence (Nakano, Gomes, Oliveira, \& Peixoto, 2017; Nakano, Miliani, Caporossi, \& Gozzoli, 2020).

\section{Procedures}

The first step of the research was to obtain approval by the Research Ethics Committee. After the parents / guardian's authorization, by means of the signing of Free and Informed Consent Forms, as well as assurance of the participants' full consent, the instrument was applied collectively in the classroom.

For data collection from the criterion group, the State Department of Education of the Brazilian Federal District authorized data collection. In the control group, data collection was performed in state and 
municipal public schools located in the State of São Paulo and Maranhão. In both groups, the instrument was applied in a single session, which lasted approximately $1 \mathrm{~h} 40 \mathrm{~min}$. There was an alternation between the subtests of intelligence and creativity. The application followed the following order: Verbal Reasoning, Abstract Reasoning, Sketch completion, Metaphor Creation, Numerical Reasoning, and Logical Reasoning.

The correction of the reasoning subtests considered the total score in each measure, as well as a total score in intelligence (sum of the scores in the four subtests). For figural creativity, the scores on the three factors that compose the activity were calculated, as well as a total score. The Metaphor Creation Test followed a correction system that had the participation of twelve judges, who received spreadsheets with all the answers to be assessed and assigned scores for each metaphor (from 0 to 3). At least two judges assessed each answer, and the final score was estimated by means of the average between the two scores.

The judges were previously trained for correcting the metaphor subtest. They were scientific initiation scholarship holders, postgraduate students in mastering and doctoring courses, and participants of a research group in psychological assessment. Previous studies with the metaphor production activity pointed out the effectiveness of the judges' participation in this activity (David, Morais, Primi, \& Miguel, 2014; Dias, Couto, \& Primi, 2009; Primi, Miguel, Couto, \& Muniz, 2007). Subsequently, the correlations between the total test scores (reasoning, figural creativity, and verbal creativity), and between each measure, were estimated by Spearman's correlation, given the absence of normality of the sample, while taking the significance level of 0.05 .

\section{Data Analysis}

To meet the proposed objectives, descriptive statistics were performed for each group and each assessed measure. The variance analysis was applied to verify the existence of difference of averages between the groups in each measure, followed by Tukey's post hoc test to identify the groups in which the difference was significant. Then, Spearman's correlation between the total score in the three measurements was estimated for each group, considering, later, the area of identification of the giftedness. The same analysis was conducted to assess the relationship between the sub-measures of each construct. Finally, the distribution of the scores obtained in the tests of reasoning, figural creativity, and verbal creativity by the groups was illustrated so that the results could be better understood. The analyses were performed using the SPSS 20.0 statistical program.

\section{Results}

After obtaining first analysis results, descriptive statistics for each of the groups, in each of the measures, were presented. That information is displayed in Table 2.

The results show that the criterion group presented higher averages in all measures evaluated, compared to the control group's performance. Among

Table 2.

Descriptive Statistics by Group

\begin{tabular}{lcccccc}
\hline Measure/Group & \multicolumn{2}{c}{ Control } & \multicolumn{2}{c}{ Academic } & \multicolumn{2}{c}{ Creative } \\
\hline Intelligence & $M$ & $D P$ & $M$ & $D P$ & $M$ & $D P$ \\
Verbal reasoning & 21,42 & 8,26 & 34,24 & 8,27 & 27,87 & 8,57 \\
Abstract reasoning & 5,67 & 1,97 & 8,45 & 2,21 & 6,91 & 2,03 \\
Numeric reasoning & 6,24 & 2,48 & 8,97 & 2,07 & 7,85 & 2,62 \\
Logical reasoning & 4,95 & 3,01 & 8,94 & 2,98 & 7,52 & 3,21 \\
Figural Creativity total & 4,57 & 3,05 & 7,88 & 2,52 & 5,61 & 2,57 \\
Elaboration & 37,61 & 19,61 & 51,12 & 18,83 & 60,23 & 18,86 \\
Emotional & 16,80 & 13,17 & 28,89 & 14,58 & 36,70 & 16,14 \\
Cognitive & 3,61 & 3,70 & 3,93 & 3,39 & 4,13 & 3,29 \\
Verbal Creativity total & 17,15 & 7,25 & 19,12 & 7,03 & 19,40 & 5,22 \\
\hline
\end{tabular}

Psico-USF, Bragança Paulista, v. 26, n. 1, p. 103-116, jan./mar. 2021 
the criteria groups, the one made up of students with academic giftedness had higher averages in the total score for intelligence and its measurements. The group with creative/productive giftedness, in turn, performed better in the measures of verbal and figural creativity. Such results were expected because of the area in which giftedness is identified.

Variance analysis was used to verify whether the differences between the groups were significant. The results were significant for all measurements: total score for intelligence $(\mathrm{F}=41.848$; $p=0.0001)$, figural creativity $(\mathrm{F}=16.884 ; p=0.0001)$ and verbal creativity $(\mathrm{F}$ $=4.001 ; p=0.003)$. Subsequently, Tukey's post hoc test indicated that the differences came from the following groups: in the measure of intelligence between the academic criterion and control group, in favor of the first $(p=0.0001)$ and between the creative criterion group and the control group, also in favor of the first group $(p$ $=0.0001)$. In figural creativity, the difference was significant between the creative/productive criterion group and the control group $(p=0.0001)$, in favor of the first and, in verbal creativity, between the academic criterion group and the control group $(p=0.010)$ in favor of the first group.

Then, the correlations between three measurements' total scores were estimated and showed different relationships between the constructs according to the group considered (Table 3). When the control group, composed of regular students, is analyzed, the results point at the existence of moderate and positive correlations between the total score in the intelligence measurement and the two measures of creativity. Regardless of the type of creativity considered, the correlation with intelligence is significant in this group.

A more in-depth analysis was then performed, categorizing the criterion group according to the area of identification of giftedness. This group was divided into two others: academic and creative/artistic. The results presented in Table 3 showed that, both in the group composed of individuals with intellectual giftedness and in the group with creative/artistic giftedness, the correlation between the measure of intelligence and figural creativity remains non-significant. That is the same result obtained when the criterion group is analyzed together, regardless of the area of identification. When it comes to the measure of verbal creativity, it is observed that, in both groups, the correlation remains significant, shown slightly lower values than those presented when the criterion group was considered as a whole, without separation of the highlighted area.

A second analysis, investigating the relationships between the measures that make up each assessed construct (four types of reasoning, three factors of figural creativity, and total score for verbal creativity), was performed. The results can be seen in Table 4 .

The data indicate that, in general, the measure of verbal creativity was the one that was most positively and significantly related to the measures of reasoning.

Table 3.

Correlation Between Total Creativity and Intelligence Measures by Group

\begin{tabular}{llll}
\hline Grupo & Intelligence & Figural Creativity & Verbal Creativity \\
\hline Control & 1 & $0,250^{* *}$ & $0,538^{* *}$ \\
Intelligence & $0,250^{* *}$ & 1 & $0,188^{* *}$ \\
Figural Creativity & $0,538^{* *}$ & $0,188^{* *}$ & 1 \\
Verbal Creativity & & & \\
Academic Giftedness & 1 & $-0,009$ & $0,450^{* *}$ \\
Intelligence & $-0,009$ & 1 & 0,032 \\
Figural Creativity & $0,450^{* *}$ & 0,032 & 1 \\
Verbal Creativity & & & \\
Creative Giftedness & 1 & 0,193 & $0,390^{*}$ \\
Intelligence total & 0,193 & 1 & $-0,197$ \\
Figural Creativity & $0,390^{*}$ & $-0,197$ & 1 \\
Verbal Creativity & & & \\
\hline
\end{tabular}

Note. ${ }^{\mathrm{p}} \leq 0,05 ; * * \mathrm{p} \leq 0,01$. 
Table 4.

Correlation between Creativity and Intelligence Sub-Measures by Group

\begin{tabular}{|c|c|c|c|c|}
\hline Group & Figural Elaboration & Figural Emotional & Figural Cognitive & Verbal Creativity \\
\hline \multicolumn{5}{|c|}{ Control group } \\
\hline VR & $0,173^{* *}$ & $0,169 * *$ & $0,074^{*}$ & $0,422 * *$ \\
\hline $\mathrm{AR}$ & $0,172^{* *}$ & $0,171 * *$ & 0,037 & $0,408^{* *}$ \\
\hline NR & $0,139 * *$ & $0,150 * *$ & 0,059 & $0,389 * *$ \\
\hline LR & $0,276^{* *}$ & $0,212^{* *}$ & $0,128 * *$ & $0,487 * *$ \\
\hline \multicolumn{5}{|c|}{ Academic giftedness } \\
\hline VR & 0,019 & 0,084 & $-0,048$ & $0,427 * *$ \\
\hline $\mathrm{AR}$ & 0,076 & 0,074 & $-0,203$ & $0,492 * *$ \\
\hline NR & $-0,003$ & 0,018 & $-0,093$ & $0,284^{*}$ \\
\hline LR & $-0,084$ & 0,154 & 0,080 & $0,314^{*}$ \\
\hline \multicolumn{5}{|c|}{ Creative giftedness } \\
\hline VR & 0,328 & 0,162 & $-0,172$ & 0,323 \\
\hline $\mathrm{AR}$ & 0,061 & 0,143 & $-0,026$ & $0,442 *$ \\
\hline NR & 0,247 & 0,174 & 0,019 & 0,180 \\
\hline LR & 0,066 & 0,090 & 0,095 & $0,364 *$ \\
\hline
\end{tabular}

Note. $\mathrm{VR}=$ verbal reasoning; $\mathrm{AR}=$ abstract reasoning; $\mathrm{NR}=$ numeric reasoning; $\mathrm{LR}=$ logical reasoning. ${ }^{*} \mathrm{p} \leq 0,05 ;{ }^{* *} \mathrm{p} \leq 0,01$.

This condition was not found only concerning the measurement of verbal and numerical reasoning in the group with creative/artistic giftedness. The measurement of figural creativity was significantly and positively related to intelligence measures only in the control group, repeating the results previously found. Among the results, it is interesting to highlight that, differently from what was expected, the creative cognitive factor presented the smallest number of significant relationships with the reasoning measures about to the results obtained for the other factors of creativity.

A possible explanatory hypothesis for the diversity found in the results is based on the fact that the variability of the results of intelligence and creativity tests between the groups is quite sharp. Explicitly considering the sum of the results in the intelligence subtests, as a general measure, it can be verified that the control group (group 3) presented a result that resembles the normal curve, which can be better visualized in Picture 1 (third graphic of Picture 1).

A very different situation is found by analyzing the criterion groups. Concerning those with academic giftedness in particular (group 1), the score variability is lower. They get higher scores than the other groups, as expected, given the essentially intellectual nature of their skills in the academic area. In the creative/artistic group (group 2), the participants' performance was not as good as in the academic group, but it was better than the one presented by the control group.

This discovery hints that a substantial difference can be found between the control and criterion groups. It is possible to observe, regarding the second group, a smaller range of results, marked mainly by the absence of individuals located at the lower end of the distribution (with a result of less than 8 points in the intelligence measure, in a situation that is opposite to the one found in the control group, in which 36 individuals presented such performance). On the other hand, there was also individuals with a performance at the upper end of the distribution (scores higher than 44 points, obtained by five individuals, and this performance was not found in the control group).

The same type of analysis then conducted for figural creativity (first Graphic of Picture 1). Again, a greater amplitude of results is found in the control sample. It is possible to observe the absence of low scores in the criterion sample (results below six points in the total figural creativity test, obtained by 33 individuals in the control group). This difference is even more significant in the creative/artistic group, in which the score range starts at 35 points. That result is much higher than the one found in the control group, as 


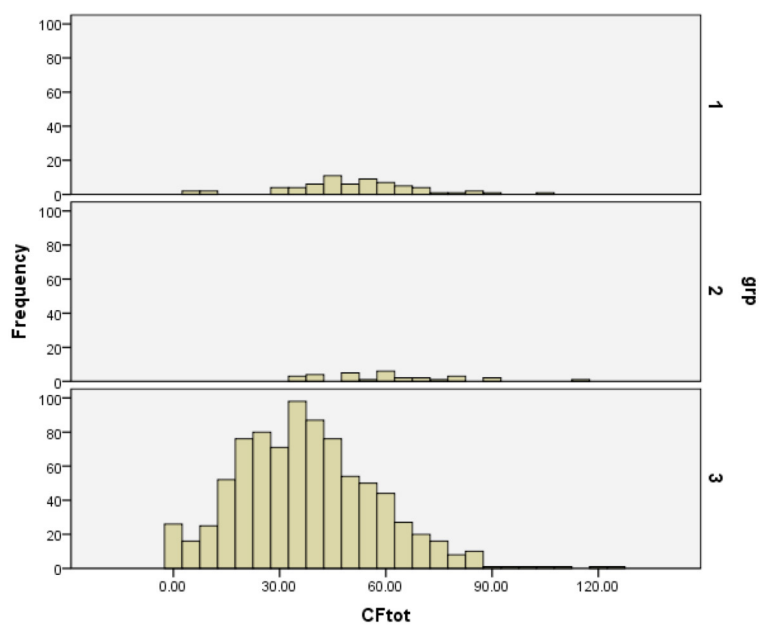

expected, given its participants' skills in the artistic area and, therefore, more related to creativity.

Finally, analyzing the results in the verbal creativity test (according to the second graphic in Picture 1), using metaphor production, it is once again possible to verify more significant variability in control group (whose scores ranged between zero and 48 points). In the sample of students with academic giftedness, this value ranges from 1 to 38 points, whereas in the artistic talent group, the variation goes from 12 to 44 points. Again, it is possible to verify a smaller number of individuals who present low scores in the criteria group, especially in the creative/artistic group, whose score starts at 12, as expected, given the participants' more developed skills in the artistic and creative area.

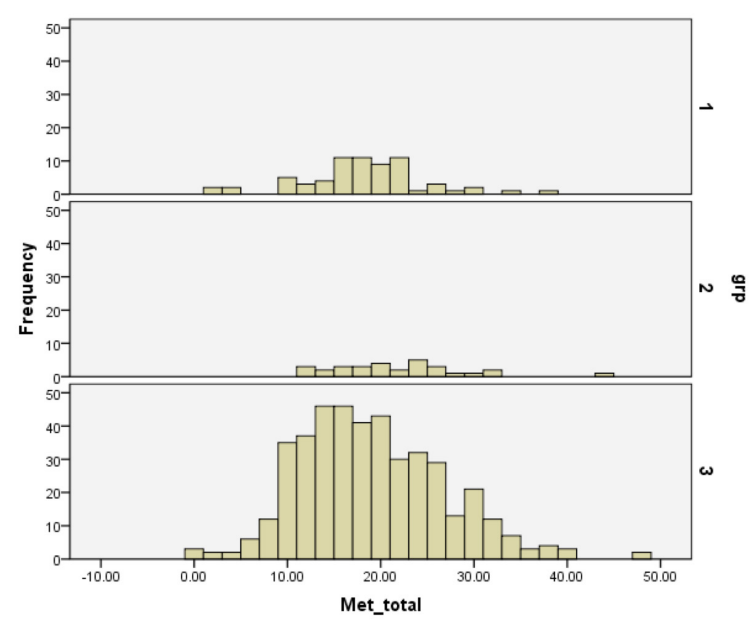

\section{Discussion}

The present study verified significant differences when investigating the relationship between the creativity/intelligence constructs in regular students and students identified with giftedness. Within this last group, differences depended on the area of identification and were under the type of creativity and intelligence assessed. Results confirmed the perception that the relationship between the constructs will depend on the creative domain and intelligence factors considered (Benedeck et al., 2014; Guignard, Kermarrec, \& Tordjman, 2016; Kandler et al., 2016; Plucker et al., 2018).

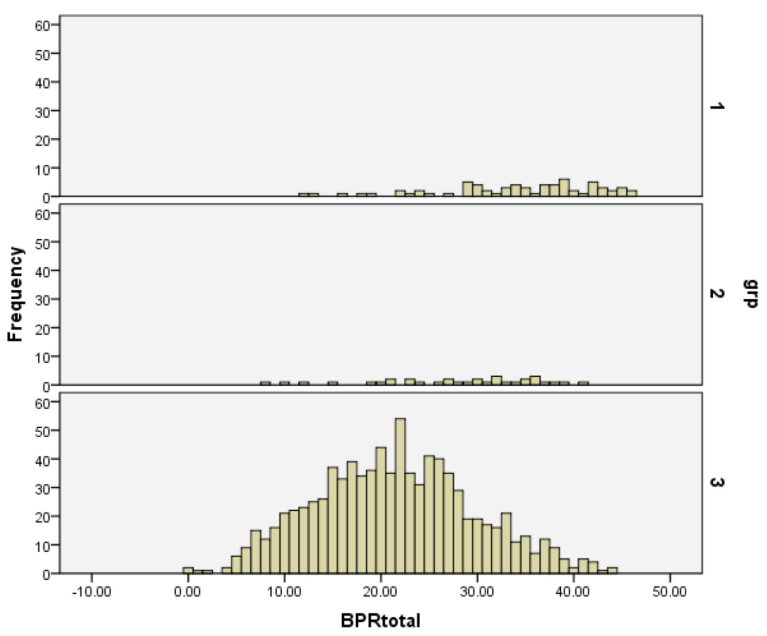

These results confirm the argument presented by Sternberg, Jarvin and Grigorenko (2011) that the meaning and magnitude of the correlation between intelligence and creativity will depend on which aspects of each construct are being measured, how they are being measured, and in which field the giftedness is manifested. In the study reported here, differences were found in the relationship between creativity and intelligence in the control group and the subgroups of the criterion group, according to the area of giftedness (academic and creative/artistic). These results confirm other findings on the subject. Preckel et al. (2006), for example, found a significant relationship between intelligence and creativity, but with very different values depending on the type of creativity measured $(r=0,54$

Note. grp: $1=$ academic giftedness, $2=$ creative giftedness, $3=$ control group. $\mathrm{CFtot}=$ figural creativity; Met_total=verbal creativity; BPRtotal $=$ reasoning total.

Figure 1. Distribution of the Scores Obtained in the Reasoning, Figural Creativity and Verbal Creativity Tests by the Groups when intelligence was correlated with general creativity; $r=0.51$ with verbal creativity; $r=0.36$ with figural creativity; and $r=0.38$ with numerical creativity).

It is essential to highlight that the literature has also indicated that intelligence has been more commonly 
associated with verbal measures of creativity. However, it is typically not a strong relationship (Kaufman, 2009). This result was founding in present study and the other ones mentioned above. Considering that the types of subtests used to assess intelligence can be described as fluid intelligence measures, it is possible to understand the significant correlations found, especially in the control group. It is important to note that several studies have hinted at the connection between fluid intelligence (ability to solve new problems) and creativity (Kaufman, Luria, \& Beghetto, 2018).

In view of the results and the scientific literature review, a second finding deserves to be highlighted. Just as the studies have pointed out differences in understanding the relationship between the intelligence/ creativity constructs in the general population, without consensus among researchers (Elisondo \& Donolo, 2010), the same situation was found when individuals with giftedness were assessed. Essential differences between the control group and criterion were also verified. The fact that all the relationships between the investigated constructs (intelligence, verbal creativity, and figural creativity) were shown to be significant only in the general population suggests that the results are closer to the threshold hypothesis (Akhtar \& Kartira, 2019; Jauk, 2013; Jauk et al., 2013; Karwowski \& Gralewski, 2012; Preckel et al., 2006; Shi, Wang, Yang, Zhang, \& Xu, 2017). It is a sign that, in the analyzed data, the correlation between the constructs was not linear, but dependent on the level of intelligence. Cho et al. (2011), for example, reported that the general intelligence factor was related to visual and verbal creativity. Still, when two groups were separated according to IQ, the relationship between the constructs was more evident in the group with average IQ.

Specifically, in the sample studied, when a greater amplitude of intelligence-related results is analyzed (control group), correlations with both types of creativity were significant and moderate. In the other groups' criteria, the correlation of intelligence with figural creativity is not significant, even presenting negative results in two of them. In this sense, the threshold concept's influence can be inferred since creativity and intelligence were conditionally related. Intelligence is fundamental, but it is not the only requirement for creativity (Neubauer \& Martskvisvili, 2018).

Considering that, in the criterion group, the intelligence relation was only associated to verbal creativity, the results confirm those obtained in the research developed by Guignard et al. (2016), in which students identified with giftedness in the verbal area presented higher scores in creative verbal tasks. However, it is essential to emphasize an important difference in the research samples: in the study reported here, students with giftedness in the specific verbal area were not assessed, so that the differences should be regarded with caution.

It is important to emphasize that results above average and close to those presented by the criterion group were also found in participants of the control group. In this case, difficulties in identifying these indicators may be preventing giftedness students from being referred for further examinations. That problem underlies the under-representation of giftedness, especially in public schools (Swanson, Russell, \& Anderson, 2019) of South America (Alencar, Fleith, \& Carneiro, 2018; Wechsler, Blumen, \& Bendelman, 2018). Schools have received guidance on how to proceed.

\section{Final Considerations}

The present study aims to investigate the relationship between intelligence and creativity, considering distinct groups. Substantial differences were found in the relationship between the constructs in the control group and the criterion group, and in the different identification areas. In regular students, without any diagnosis of giftedness, the relationship between intelligence and the two types of creativity was positive and significant, whereas in the identified students, only verbal creativity was related to intelligence. The same situation was observed when the criterion sample was considered general, and when the identification areas were considered separately (academic and creative/artistic).

Some hypotheses were thought of as a way to interpret the findings. The review of models of creativity and intelligence (which began to be visualized within broader and multidimensional models), the emergence of more modern and sophisticated methods of analysis, and the expansion of the understanding of giftedness (no longer restricted to intelligence or giftedness of the academic type) can be cited as conditions that have led to a more effective understanding of the relationship between the constructs. If we assume that the relationship exists, as has been empirically proven, the need to stimulate both skills equally is justified, becoming a task that both traditional schools and giftedness care programs must take for themselves. Understanding the existing similarities and differences, and the relationship 
between those populations, will allow professionals to work with students helping them to achieve success in activities that require such skills, individually or in combination.

One of the limitations of the research concerns the difference in the number of participants of the control group and the criterion group due to reasons already mentioned. As well as to the choice of instruments, so that the results should be interpreted with caution since they reflect only the aspects that were assessed (figural and verbal creativity or the types of reasoning involved). Future studies involving other areas in which giftedness can be identified, and different measuring instruments, may confirm the results presented here, expanding knowledge about the relationship between creativity and intelligence.

\section{References}

Aguirre, K., \& Conners, F. (2010). Creativity and intelligence in preschoolers: preliminary findings. The University of Alabama McNair Journal. Retrieved from http://graduate.ua.edu/mcnair/journals/2010/ Aguirre.pdf.

Akhtar, H., \& Kartira, Y. (2019). Intelligence and creativity: an investigation of threshold theory and its implications. Journal of Educational Sciences and Psychology, IX(LXXI), 131-138. Retrieved from https://eds.a.ebscohost.com/eds/pdfviewer/ pdfviewer?vid $=1 \&$ sid $=3 \mathrm{c} 7 \mathrm{bb} 6 \mathrm{~d} 1-\mathrm{e} 4 \mathrm{c} 3-4 \mathrm{fc} 8-\mathrm{b} 27 \mathrm{e}-$ -ca965d092045\%40sdc-v-sessmgr01.

Alencar, E. M. L. S., Fleith, D. S., \& Carneiro, L. B. (2018). Gifted Education in Brazil: historical background, current practices and research trends. In B. Wallace, D. A. Sisk, \& J. Senior (Eds.), The SAGE handbook of gifted and talented education (pp. 432-445). 55 City Road: SAGE Publications. http://doi. org/10.4135/9781526463074.n36.

Alves, R. J. R., \& Nakano, T.C. (2014). Creativity and intelligence in children with and without developmental dyslexia. Paideia, 24(59), 361-369. http:// doi.org/10.1590/1982-43272459201410.

Alves, R. J. R. \& Nakano, T. C. (2015). Desempenho criativo e suas relações com diferentes medidas de inteligência em crianças com dislexia do desenvolvimento: um estudo exploratório. Psicologia Reflexão e Crítica, 28(2), 280-291. http://doi. org/10.1590/1678-7153.201528208.
Barros, D. P., Primi, R., Miguel, F. K., Almeida, L., \& Oliveira, E. P. (2010). Metaphor Creation: A Measure of Creativity or Intelligence? European Journal of Education and Psychology, 3 (1), 103-115. Retrieved from http://www.redalyc.org/ pdf/1293/129313736008.pdf.

Batey, M., Furnham, A., \& Safiullina, X. (2010). Intelligence, general knowledge and personality. Learning and Individual Differences, 20, 532-535. http://doi. org/10.1016/j.lindif.2010.04.008.

Beauty, R.E., \& Silvia, P.J. (2012). Metaphorically speaking: cognitive abilities and the production of figurative language. Memory and Cognition, 41 (2), 255267. http://doi.org/10.3758/s13421-012-0258-5

Benedek, M., Franz, F., Heene, M., \& Neubauer, A. C. (2012). Differential effects of cognitive inhibition and intelligence on creativity. Personality and Individual Differences, 53 (4), 480-485. http://doi./ org/10.1016/j.paid.2012.04.014

Benedek, M., Jauk, E., Sommer, M., Arendasy, M., \& Neubauer, A. C. (2014). Intelligence, creativity, and cognitive control: The common and differential involvement of executive functions in intelligence and creativity. Intelligence, 46, 73-83. http://doi. org/10.1016/j.intell.2014.05.007.

Brasil (2010). Politicas públicas para alta habilidade/ superdotação. Retrieved from http://www.senado. gov.br/comissoes/CE/AP/AP20080626_superdotados_CláudiaGriboski.pdf

Cho, S. H., Nijenhuis, J. T., Van Vianen, A. E. M., Kim, H., \& Lee, K. H. (2011). The relationship between diverse components of intelligence and creativity. The Journal of Creative Behavior, 44(2). https://doi. org/10.1002/j.2162-6057.2010.tb01329.x

Cramond, B., Kim, K. H., \& VanTassel-Baska, J. (2010). The relationship between creativity and intelligence. In J. C. Kaufman \& R. J. Sternberg (Eds.), The Cambridge handbook of creativity (p. 395-412). Cambridge University Press. https://doi.org/10.1017/ CBO9780511763205.025

David,A.P.,Morais,M.D.F.,Primi,R.,\&Miguel,F.K.(2014). Metáforas e pensamento divergente: criatividade, escolaridade e desempenho em Artes e Tecnologias. Avaliação Psicológica, 13(2), 147-156. Retrieved from http://pepsic.bvsalud.org/scielo.php?script $=$ sci_ arttext\&pid $=$ S1677-04712014000200002\&lng $=$ pt \&nrm $=$ iso\&tlng $=$ pt. 
Dias, A. R., Couto, G. \& Primi, R. (2009). Avaliação da criatividade por meio da produção de metáforas. Psico, 40 (2), 210-210. Retrieved from https:// revistaseletronicas.pucrs.br/ojs/index.php/ revistapsico/article/view/1514

Elisondo, R. C., \& Donolo, D. S. (2010). ¿Creatividad o inteligencia? That is not the question. Anales de Psicologia, 26 (2), 220-225. Retrieved from http:// www.redalyc.org/articulo.oa?id=16713079004.

Ferrando, M., Soto, G., Prieto, L., Sáinz, M., \& Ferrándiz, C. (2016). Synthetic-creative intelligence and psychometric intelligence: analysis of the threshold theory and creative process. Turkish Journal of Giftedness and Education, 6(2), 88-98. Retrieved from https:// eric.ed.gov/?id=ED572336.

Flores-Mendoza, C., Ardila, R., Rosas, R., Lucio, M. E., Gallegos, M., \& Colareta, N. R. (2018). Intelligence measurement and school performance in Latin America. Switzerland: Springer.

Gonçalves, F.C., \& Fleith, D.S. (2011). Estudo comparativo entre alunos superdotados e não-superdotados em relação a medidas de inteligência e criatividade. Psico, 42(2), 263-268. Retrieved from http://revistaseletronicas.pucrs.br/revistapsico/ojs/index. $\mathrm{php} /$ revistapsico/article/view/7154

Guignard, J., Kermarrec, S., \& Tordjman, S (2016). Relationships between intelligence and creativity in gifted and non-gifted children. Learning and Individual Differences, 52, 209-215. http://doi. org/10.1016/j.lindif.2015.07.006

Harris, A. M., Williamson, R. L., \& Carter, N. T. (2019). A conditional threshold hypothesis for creative achievement: On the interaction between intelligence and openness. Psychology of Aesthetics, Creativity, and the Arts, 13(3), 322-337. http://doi. org $/ 10.1037 /$ aca0000182

Jauk, E. (2013). The relationship between intelligence and creativity: new support for the threshould hypothesis by means of empirical breakpoint detection. Intelligence, 41(4), 212-221. http://doi. org/10.1016/j.intell.2013.03.003.

Jauk, E., Benedek, M., Dunst, B., \& Neubauer, A. C. (2013). The relationship between intelligence and creativity: New support for the threshold hypothesis by means of empirical breakpoint detection. Intelligence, 41(4), 212-221. http://doi. org/10.1016/j.intell.2013.03.003.
Kandler, C., Rieman, R., Angleitner, A., Spinath, F. M., Borkenau, P., \& Penke, L. (2016). The nature of creativity: the roles of genetic factors, personality traits, cognitive abilities and environmental sources. Journal of Personality and Social Psychology, 111(2), 230-249. http://doi.org/10.1037/pspp0000087.

Karwowski, M. \& Gralewski, J. (2012). Threshold hypothesis: Fact or artifact? Thinking Skills and Creativiy, 8, 25-33. http://doi.org/10.1016/j. tsc.2012.05.003.

Kaufman, J. C., Luria, S. R., \& Beghetto, R. A. (2018). Creativity. In S. I. Pfeiffer (Ed.), APA Handbook of Giftedness and Talent (pp. 287-298). Washington: American Psychological Association.

Kaufman, J. C., \& Plucker, J. A. (2011). Intelligence and creativity. In R. J. Sternberg \& S. B. Kaufman (Eds.), The Cambridge handbook of intelligence (pp. 771-783). Cambridge: Cambridge University Press.

Kaufman, S. B. \& Sternberg, R. J. (2008). Conceptions of giftedness. In S. Pfeiffer (Ed.), Handbook of giftedness in children: Psycho- Educational theory, research and best practices (pp. 71-91). New York: Springer.

Lee, C. S., Huggins, A. C., \& Therriault, D. J. (2014). A measure of creativity or intelligence? Examining internal and external structure validity evidence of the Remote Associates Test. Psychology of Aesthetics, Creativity, and the Arts, 8(4), 446-460. http://doi. org $/ 10.1037 /$ a0036773.

Li, H., Lee, D., Pfeiffer, S. I., Kamata, A., Kumtepe, A. T., \& Rosado, J. (2009) Measurement invariance of the Gifted Rating Scales - school form across five cultural groups. School Psychology Quarterly, 4 (3), 186- 198. http://doi.org/10.1037/a0017382

Liu, X., Liu, L., Chen, Z., Song, Y., \& Liu, J. (2019). Indirect Effects of Fluid Intelligence on Creative Aptitude Through Openness to Experience. Current Psychology, 38, 563-571. http://doi.org/10.1007/ s12144-017-9633-5

Lynch, S. F. \& Kaufman, J. C. (2019). Creativity, intelligence, and wisdom: Could versus should. In R. J. Sternberg \& J. Glück (Eds.), The Cambridge handbook of wisdom (p. 455-464). Cambridge University Press. http://doi.org/10.1017/9781108568272.021

Maia-Pinto, R. R., \& Fleith D. S. (2004). Avaliação das práticas educacionais de um programa de atendimento a alunos superdotados e talentosos. 
Psicologia Escolar e Educacional, 8(1), 55-66. http:// dx.doi.org/10.1590/S1413-85572004000100007.

Mendonça, P. V. C. F. \& Fleith, D. S. (2005). Relação entre criatividade, inteligência e autoconceito em alunos monolingues e bilíngües. Psicologia Escolar e Educacional, 9, 59-70. http://dx.doi.org/10.1590/ S1413-85572005000100006.

Milian, Q. G, \& Wechsler, S. M. (2018). Evaluación integrada de la inteligencia y creatividad. Revista de Psicología, 36(2), 525-548. http://doi.org/10.18800/ psico.201802.005

Miroshnik, K. G. \& Shcherbakova, O. V. (2019). The proportion and creativity of "old" and "new" ideas: are they related do fluid intelligence? Intelligence, 76 (online publication). http://doi.org/10.1016/j. intell.2019.101384

Mourgues, C. V., Tan, M., Hein, S., Al-Harbi, K., Aljudghaiman, A., \& Grigorenko, E. L. (2016). The relationship between analytical and creative cognitive skills from middle childhood to adolescence: testing the threshold theory in the Kingdom of Saudi Arabia. Learning and Individual Differences, 52, 137-147. http://doi.org/10.1016/j. lindif.2015.05.005.

Nakano, T. C. (2012). Criatividade e inteligência em crianças: habilidades relacionadas? Psicologia Teoria e Pesquisa, 28(2), 149-160. http://doi.org/10.1590/ S0102-37722012000200003.

Nakano, T. C. (2017). Avaliação psicométrica das habilidades cognitivas: relação entre inteligência e criatividade. In A. M. R. Virgolim (Ed.), Altas habilidades/superdotação, inteligência e criatividade (pp. 99-118). Campinas: Papirus.

Nakano, T. C. (2018). Explorando a relação entre criatividade e inteligência. In C. S. Hutz, D. R. Bandeira, \& C. M. Trentini (Eds.), Avaliação psicológica da inteligência e da personalidade (pp.155-172). Porto Alegre: Artmed.

Nakano, T. C. \& Brito, M. E. (2013). Avaliação da criatividade a partir do controle do nível de inteligência em uma amostra de crianças. Temas em Psicologia, 21(1), 1-15. http://doi.org/10.9788/TP2013.1-01.

Nakano, T.C., Gomes, L.B., Oliveira, K.S., \& Peixoto, E.M. (2017). Validity study of intelligence subtests for a Brazilian giftedness assessment battery. Estudos e Pesquisas em Psicologia, 17(1),
386-405. Retrieved from http://pepsic.bvsalud. org/scielo.php?script $=$ sci_arttext\&pid $=\mathrm{S} 1808$ $-42812017000100021 \& \operatorname{lng}=$ pt\&tlng $=$

Nakano, T.C., Miliani, A.F.M., Caporossi, D.C., \& Gozzoli, M.Z. (2020). Evidências de validade do subteste de criatividade verbal da bateria de avaliação das altas habilidades/superdotação. Revista Ibero-Americana de Criatividade e Inovação, 1(1), 13-25. Retrieved from https://recriai.emnuvens.com.br/ revista/article/view/20/4

Nakano, T. C. \& Primi, R. (2012). Bateria de avaliação das altas habilidades/superdotação (BAAH/S). Não publicado.

Nakano, T. C., Primi, R., Abreu, I. C. C., Gozzoli, M. Z., Caporossi, D. C., Miliani, A. F. M., Martins, A. A. (2015). Bateria para avaliação das altas habilidades/superdotacão: análise dos itens via Teoria de Resposta ao Item. Estudos de Psicologia (Campinas), 32(4), 729-741. http://doi. org/10.1590/0103-166X2015000400016.

Nakano, T. C., Primi, R., Ribeiro, W. J., \& Almeida, L. S. (2016). Multidimensional assessment of giftedness: criterion validity of Battery of Intelligence and Creativity Measures in predicting arts and academic talents. Anales de Psicologia, 32(3), 628-637. http://doi.org/10.6018/analesps.32.3.259391.

Nakano, T. C., Wechsler, S. M., Campos, C. R., \& Milian, Q.G. (2015). Intelligence and creativity: relationship and their implications for Positive Psychology. Psico-USF, 20(2), 195-206. http://doi. org/10.1590/1413-82712015200201.

Neubauer, A. C. \& Martskvisvili, K. (2018). Creativity and intelligence: A link to different levels of human needs hierarchy?. Heliyon 4, e00623. https://doi. org/10.1016/j.heliyon.2018.e006232405-8440/ Ó2018

Partnership for 21st Century Skills. (2013). Framework for 21st century learning. Washington, DC: Author. Retrieved from http://www.p21.org/ our-work/ p21-framework.

Pereira, M. (2001). Inteligência e criatividade: duas trajectórias alternativas para as crianças sobredotadas?. Psicologia: Teoria, Investigacãa e Prática, 6(1), 171-188.

Plucker, J. A., Beghetto, R., \& Daw (2004). Why creativity is domain general, why it looks domain 
specific, and why the distinction does not matter. In R. J. Sternberg, E. L. Grigorenko, \& J. L. Singer (Eds.), Who's creative? (pp. 153-167). Washington: American Psychological Association.

Plucker, J. A., Guo, J., \& Makel, M. (2018). Creativity. In S.I Pfeiffer (Ed.), Handbook of Giftedness in Children (pp. 81-99). Singapore: Springer.

Preckel, F., Holling, H., \& Wiese, M. (2006). Relationship of intelligence and creativity in gifted and non-gifed students: an investigation of threshold theory. Personality and Individual Differences, 40(1), 159-170. http://doi.org/10.1016/j.paid.2005.06.022.

Primi, R., Miguel, F.K., Couto, G. \& Muniz, M. (2007). Precisão de avaliadores na avaliação da criatividade por meio da produção de metáforas. PsicoUSF, 12 (2), 197-210. http://dx.doi. org/10.1590/S1413-82712007000200008

Primi, R. \& Nakano, T.C. (2015). Inteligência. In F. H. Santos, V. M. Andrade \& O. F. A. Bueno (Orgs.), Neuropsicologia Hoje (pp. 49-58). Porto Alegre: Artmed.

Renzulli, J. S. (2020). O que estamos fazendo de errado na educação de superdotados? Estamos deixando de fora uma grande quantidade de estudantes com alto potencial. Revista Ibero-Americana de Criatividade e Inovação, 1(1), 1-3. Retrieved from https://recriai. emnuvens.com.br/revista/article/view/17/1.

Ribeiro, W. J., Nakano, T. C., \& Primi, R. (2014). Validade da estrutura fatorial de uma bateria de avaliação de altas habilidades. Psico, 45(1), 100-109. Retrieved from http://revistaseletronicas.pucrs. br/fadir/ojs/index.php/revistapsico/article/ view/13636/11446.

Shi, B., Wang, L., Yang, J., Zhang, M., \& Xu, L. (2017). Relationship between divergent thinking and intelligence: an empirical study of the threshold hypothesis with Chinese children. Frontiers in Psychology, 8(116). http://doi.org/10.3389/ fpsyg.2017.00254

Silvia, P. J., \& Beaty, R. E. (2012). Making creative metaphors: the importance of fluid intelligence for creative thought. Intelligence, 40(4), 343- 351. https://doi.org/10.1016/j.intell.2012.02.005

Silvia, P. J., Beaty, R. E., \& Nusbaum, E. C. (2013). Verbal fluency and creativity: General and specific contributions of broad retrieval ability (Gr) factors to divergent thinking. Intelligence, 41, 328-340. https://doi.org/10.1016/j.intell.2013.05.004

Souza, A. A. F., \& Wechsler, S. M. (2013). Inteligência e criatividade na maturidade e velhice. Psicologia: Reflexão e Crítica, 26(4), 643-653. https://doi. org/10.1590/S0102-79722013000400004.

Sternberg, R. J. (2001). What is the common thread of creativity? Its dialectical relation to intelligence and wisdom. American Psychologist, 56(4), 360-362. https://doi.org/10.1037/0003-066X.56.4.360

Sternberg, R. J., Jarvin, L., \& Grigorenko, E. L. (2011). Explorations in Giftedness. New York: Cambridge University Press.

Sternberg, R. J., \& O’Hara, L. A. (2000). Intelligence and creativity. In R. J. Sternberg (Ed.). Handbook of intelligence (pp. 611-630). New York, NY: Cambridge University Press.

Swanson, J. D., Rusell, L. W., \& Anderson, L. (2019). A model for growing teacher talent scouts: decreasing underrepresentation of gifted students. In S.R Smith (Ed.), Handbook of giftedness and talent development in the Asia-Pacific (pp. 1-20). Singapore: Springer. http://doi.org/10.1007/978-981-13-3021-6_55-1

Virgolim, A.M.R. (2005). Creativity and intelligence: $A$ study of Brazilian gifted and talented students. Tese de Doutorado, University of Connecticut, Estados Unidos. Retrieved from https://opencommons. uconn.edu/dissertations/AAI3193748

Wechsler, S. M., Blumen, S., \& Bendelman, K. (2018). Challenges on the identification and development of giftedness in South America. In S.I. Pfeiffer (Ed.), APA Handobook of Giftedness and Talent (pp. 97-112). Washington: APA.

Wechsler, S. M., Nunes, M. F. O., Schelini, P. W., Ferreira, A. A., \& Pereira, D. A. P. (2010). Criatividade e inteligência: analisando semelhanças e discrepâncias no desenvolvimento. Estudos de Psicologia (Natal), 15(3), 243-250. https://doi. org/10.1590/S1413-294X2010000300003

Welter, M. M., Jaarsveld, S., Leeuwen, C., \& Lachmann, T. (2016). Intelligence and creativity: over the threshold together? Creativity Research Journal, 28(2), 212-218. doi: 10.1080/10400419.2016.1162564

Recebido em: 13/04/2020

Reformulado em: 02/07/2020

Aprovado em: 01/09/2020 
About the authors:

Tatiana de Cassia Nakano - Graduation, master and PhD in Psychology from the Pontifical Catholic University of Campinas. Professor of the post graduate program in psychology at the Pontifical Catholic University of Campinas. ORCID: https://orcid.org/0000-0002-5720-8940

E-mail: tatiananakano@hotmail.com

Walquiria de Jesus Ribeiro - Psychologist by the Federal University of Maranhão. Specialist in Neuropsychology from the Faculty of Medicine of the University of São Paulo. Master in Psychology from the Pontifical Catholic University of Campinas

ORCID: https://orcid.org/0000-0001-9317-4074

E-mail:walquiriaribeiro@hotmail.com

Angela Magda Rodrigues Virgolim - Graduation and Master in Psychology, both from the University of Brasília. $\mathrm{PhD}$ in Educational Psychology from the University of Connecticut. Adjunct professor at the Department of Basic Psychological Processes (PPB) of the Institute of Psychology at the University of Brasilia.

ORCID: https: / /orcid.org/0000-0001-5493-080X

E-mail: angela.virgolim@gmail.com

\section{Contact:}

Programa de Pós-Graduação em Psicologia

Avenida John Boyd Dunlop, s/n, Jardim Ipaussurama

Campinas-SP, Brasil

CEP: 13060-904 